away from this department, I can safely say that every single major line of research at present being pursued here would stop at once". Support for Prof. Happold's plea came from the body of the meeting during discussion periods, and it was clear that a strong feeling existed that university departments urgently need greater financial support from within the universities themselves.

Two further inter-related points which emerged from the colloquium were, first, that biochemistry is still primarily a research subject, and secondly, that there is already a shortage of trained biochemists in Britain. In relation to the first point, Dr. Robinson produced some interesting figures which suggested that comparatively few biochemists are employed in industry and that, generally speaking, they tend to take subordinate roles. However, Dr. Robinson did stress that his figures related particularly to the pharmaceutical industry, and it seems to the present writers that reference to other industries, for example, the food industry, might provide a more favourable picture. On the second point, Sir William Slater pointed out that it has become increasingly difficult to obtain suitably qualified research biochemists and that the brakes on the progress of the biochemical work of the Agricultural Research Council have not been shortage of funds but shortage of the right men. Further point was given to this statement by Dr. Marrian, who said that the development of the work of the Imperial Cancer Research Fund and the opening of its new Institute will mean that the number of qualified research workers employed by the Fund will increase from the present level of about 30 to between 80 and 100 by $1964-65$. Approximately one-third of these will probably be biochemists. At the present rate at which trained biochemists are emerging from the universities, one suspects that Dr. Marrian will experience difficulty in recruitment on this scale.

In his summarizing remarks, Prof. Neuberger struck at the very root of this problem by pointing out that several British universities do not yet have departments of biochemistry, and he appealed to the Iniversities to see that this defect is speedily remedied. In his own University of London, although there are a number of biochemistry departments concerned with the instruction of medical students, there are only two departments catering for a science degree in the subject, and the combined intake of these departments is limited to about twenty students a year. Prof. Neuberger further stressed the frustration felt by university biochemists of high standing who are unable to progress to senior status because of the rigidity of establishment. He pleaded for the speedy creation of new chairs of biochemistry and the introduction of personal chairs in this and related subjects. Citing the case of Harvard University, with its five professors within what is probably the best organic chemistry department in the world, Prof. Neuberger said that this is one aspect of the American university system that we should be prepared to adopt.

Bearing in mind the comments of Dr. Robinson regarding the subordinate position of biochemists in industry, Prof. Neuberger suggested that it might be time to do some re-thinking as to the way in which biochemists in Britain are trained. For example, is a training in organic chemistry being given which is sufficient for the needs of industry? Should the universities encourage the biochemist who is perhaps not ideally suited for a research position to think of a teaching post in a grammar or public school ? The student population of the schools might then become more aware of the possibilities of biochemistry as a career, and this in turn might stimulate the flow of recruits to the profession.

During the two periods which were allocated to discussion, many members of the audience took the opportunity to ask questions and to state their own views. From later discussions which took place during an informal supper, it was clear that the colloquium had been a most successful venture and, in particular, many people expressed their appreciation of the co-operation of the various research councils and similar organizations in providing such interesting accounts of their activities. The meeting has raised a number of points which appear to merit further investigation and a number of problems which, it seems to the present writers, should now be actively pursued by the Biochemical Society for the good of British biochemistry and, indeed, for science as a whole.

K. S. DODGSON

J. Pryde

\title{
RESEARCH FOR INDUSTRY
}

" $\mathrm{R}$ ESEARCH for Industry 1959"* follows the general pattern of the previous year's report. The report of the Industrial Grants Committee, which this year discusses the coverage of the Government scheme and co-operation in three specific areascreep research, fatigue of metals and shipbuilding research-is accompanied by a review of the achievements of a dozen of the Associations, the terms of grant of which have been reviewed during the year; and, under "The Research Associations To-day", there is the now customary list of Associations, giving their officers, income, publications and a brief indication of the present scope of the work of each Association. To the total income of the Associations

* Department of Scientific and Industrial Research. Research for Industry 1959: a Report on work done by Industrial Research Associations in the Government Scheme. Pp. iv $+126+12$ plates.
(London: H.M. Stationery Office, 1960.) 8s. net. in 1959 of $£ 7.3$ million, the Department of Scientific and Industrial Research contributed $£ 1 \cdot 7$ million.

In place of the two special chapters in last year's report dealing with the place of the research associations in the evolution of scientific endeavour and the service of co-operative research to the textile industry, there is a chapter by Dr. $J$. Thomson on instrumentation and automatic control in industry, which surveys briefly recent progress in this field in various industries, particularly under the headings of detecting elements, indicators and recorders, and controllers. The British Scientific Instrument Research Association seeks first to serve the scientific instrument industry and secondly, to bring large users of instruments into contact with manufacturers. Besides current investigations into the structure and control of thin films, of glassy phosphors, particularly 
as detectors of high-speed neutrons, and of the parameters of optical receiving systems with particular reference to frequency response measurements, the Association has just completed the development of an ultrasonic flowmeter, under the sponsorship of the National Research Development Corporation. The Industrial Grants Committee stresses its anxiety to foster a free exchange of information in this field between the many research associations concerned.

In regard to coverage, the Industrial Grants Committee notes that the admission of the Water Research Association, which in its new premises at Medmenham, Bucks, will be concerned with rapid methods of water filtration, algal growth in stored waters, and the disposal and reclamation of waterworks sludge, brought for the first timo the number of organizations in the Government scheme to fifty. Only forty-one of these bodies, however, have the formal and permanent status of a rescarch association; the others, with the title, usually, of research council, committee or organization, being as a rule young concerns in an experimental stage. Stress is laid on the need to increase greatly the scalc of research on creep. The new building being erected at the National Engineering Laboratory for completion in 1961 will permit basic researches to be expanded with the view of obtaining a better understanding of the ereep process and of those properties relevant to the successful use of engineering materials at high temporatures ; in the meantime, a Creep Information Centre has been opened to enable industrial designers to obtain creep data not at present readily available in a co-ordinated form. The Electrical Rosearch Association is also planning an extended programmo of tests to provide now information on those ranges of steels and temperatures of particular relevance to modern steam-raising plant and turbinos, especially for generating electric power. The National Physical Laboratory will analyse and cvaluate the relevant metallurgical data obtained on a range of selectod steels, and co-operative crcep tests are being made by several stcel firms organized through a committee of the British Iron and Steel Research Association.

A committee of nine members, under the chairman. ship of Sir Alfred Pugsley, has been set up to consider what research needs to be done into the fatigue of ongineering structures made of metal, to survey existing research facilities and to make recommendations to the Department. In regard to shipbuilding research, besides tho work of the British Shipbuilding Research Association and Parsons and Marine Engineering Turbine Research and Development Association, which is specially roviowed in the report, much useful work on ship hydrodynamics has been done at the National Physical Laboratory, and it is intended to concentrate in the new laboratory at Feltham all research and commercial tests relating to rough water and all work on steering and manceuvring problems, and to conduct smooth-water tests at Teddington. Tho Industrial Grants Committeo is encouraging as much flexibility as possible in the programmes of the two rescarch associations, and the report refers to the virtual completion by the British Shipbuilding Research Association of an extensivo methodical series of hydrodynamic oxperiments on models of ocean-going merchant ship forms, the charts compiled from which should provido naval architects with a standard work of reference for estimating the resistance and powor required for propulsion of any new form of ship's hull within a wide range of variables. The $\Lambda$ ssociation also operates an establishment for testing full-scale components of ships' structures and is concerned with all types of propelling and auxiliary machinery on ships, other than steam and gas turbines, which are dealt with by the Parsons and Marine Fngineering Turbine Research and Development Association. Research and design studies by this Association havo led to the production of turbine machinery of advanced design, with a 27.5 per cent reduction in overall fuel consumption and a 53 per cent reduction in the weight of marine turbines and gearing between 1945 and 1958. A special hydraulic transmission has been developed with ahead and astern units, together with a friction clutch for running ahoad under steady conditions. 'Tests on a small steam turbine at temperatures up to $1,150^{\circ} \mathrm{F}$. have yielded much valuable information, and an expcrimental liquid. cooled single-stage gas turbine has been designed which shows promise of giving appreciably better performances than the steam turbine. Full-scale tests of hardened and ground naval gears, and through-hardoned merchant-marine gears have permittod designs of higher loading to be applied to the propulsion of merchant ships.

Among recent achievemonts of the British Cast Iron Research Association noted in this report may be mentioned outstanding progress in work on the causes and elimination of defects in iron castings, its development of a successful external system of dust control for stand grinders in fettling shops, the establishment of much more precise correlations between mechanical properties and structure of cast iron and between melting processes and properties, and the completo definition of the conditions for producing shock-resistant nodular cast iron. The British Steel Castings Research Association's steelmaking scction has constructed control curves permitting prediction, for any temperature of steel-bath and any initial oxygen content, of the amount of oxygen to be injected after the carbon flame appears in order to give a predetermined reduction in the carbon content of the bath. Other work seeks to provide basic data on the physical properties of cast steel, and the Association is also studying the control of both dust and noiso when using portable fettling tools.

The File Research Couneil has established a maximum forging tempcrature by studying the metallurgical treatment of high-carbon file steol, and a study of metal flow during tooth-cutting has enabled the relation between tooth shape and chisel angles to be detormined. The British Welding Research Associa. tion's tests of welded stcel plates $3 \mathrm{ft}$. wide and $I$ in. and $3 \mathrm{in}$. thick have establishod the relative importance in brittle fracture of weld defects, residual stresses, and quality of steel, and extensive work on the welding metallurgy of aluminium alloys has facilitated the selection of filler alloys. Fatigue tests have confirmed the serviccability of butt. welded pipes provided the root-run is sound and the penetration bead is smooth. The Chalk, Lime and Allied Industries Research Association, now in its fifth year, has bcon concerned chiofly with possible new uses for lime, the examination of factors affecting the quality of lime, and with the manufacture and use of sand-lime bricks. The Research Council of the British Whiting Federation has clearly indicated tho possibility of considerable improvements in whiting manufacture by producing a range of 
more uniform and finer-quality powders, and its work on quality control and grading has led to the adoption of a comprehensive system of grading by size characteristics, with limits for chemical impurities.

Basic research by the British Leather Manufacturers' Research Association in the past five years has been concerned with the hide and skin proteins and the isolation and identification of constituents of vegetable tanning materials. In applied research the advantage of sodium chlorite over sodium hyperchlorite as an antiseptie in soaking has been demonstrated, and a water-proofing process developed in which the addition of rubbery polymers to the silicone solution greatly reduces the amount and cost of silicone needed. An intensive study of batch tannages in the laboratory and on the small-works scale enabled the duration of vegetable tanning to be reduced from 6-12 weeks to 14-21 days. The Hosiery and Allied Trades Research Association has given considerable help in the development of new knitting and wet- processing techniques for tailored synthetic fibre yarns, and suggested a scheme for the continuous processing of nylon hose. 'The British Launderers' Research Association has established the practicability of medium-temperature washing and cold-water rinsing, and has set up a Special Projects Group to investigate and develop new methods and equipment which should permit laundering on a continuous-flow basis. Psychological tests on apprentices in nineteen firms by the National Institute of Industrial Psychology havo yielded a good correlation between performance at the tests and performance at technical colleges, and the tests should give a valuable forecast of probable performance during apprenticeship. Work still in progress includes inquiries into relations between satisfaction and efficiency at work, between management structure and managers' satisfaction and effectiveness in their work, methods of measuring 'personal' values relevant to people's occupations and the development of new tests of colour vision and colour-matching skills.

\section{THE FRANKLIN INSTITUTE}

\begin{abstract}
A $T$ the annual meeting of the Franklin Institute held on January 20 , the president, Mr. W. L. LePage, gave a summary of the activities of the Institute during 1959, and presented the annual report of the board of managers for $1959^{*}$.

The year 1959 marked the one hundred and thirtyfifth anniversary of the founding of the Institute and the twenty-fifth of its fine building on the Parkway, Philadelphia, and the report makes special mention of the remarkable growth of the Institute's activities since its modest beginning in 1824 as an organization for the mutual benefit of a few citizens of Philadelphia. To illustrate the Institute's present wide sphere of influence, the highlights of the activities for 1959 are presented in the annual report in the form of a spiral, the focus of which is taken as at the Institute's headquarters in Philadelphia and the unbroken curves of which reach out through the Delaware Valley, the nation, the world, and the universe beyond our planet. Each of these areas is taken as the title of one of the sections of the report, and the Institute's activities are discussed according to the area in which their contributions to science were the largest.
\end{abstract}

Five of the Institute's main activities-the Science Museum, the Astronomy Department, the educational radio and television programmes, the science meetings, and the Library-are confined almost entirely to Philadelphia and the Delaware Valley. The number of visitors to the Museum during 1959 was 410,433 , of whom approximately 290,000 were school children. Sixteen permanent exhibitions were added during the year, of which the two most spectacular were the full-size Matador missile and the smoke tunnel in the Hall of Aviation. The demonstration, "Our Biggest Satellite-the Moon", which was shown in the Astronomy Department during September-October, proved extremely popular since that period coincided with the launchings of the Lunik II and Lunik III. Other exhibits included a Vanguard exhibit and a

* A summary and full text of the illustrated report appear in the April issue of the Journal of the Franklin Institute $(269,315 ; 1960)$. model of the $600-\mathrm{ft}$. radiotelescope which is being erected in Virginia. The radio and television programmes for schools in the area consisted of a weekly series of radio broadcasts covering science subjects and six television broadcasts featuring aspects of work being carried out in the Institute's laboratories. The titles of the twenty-one lectures presented at the Institute's meetings are listed in the report. They include, "The Impact of the International Geophysical Year on Science and Engineering" given by $\mathrm{H}$. Odishaw ; "Fundamental Particles" by H. A. Bethe; "The Fuel Cell" by H. A. Liebhafsky; and "The Science of Yesterday, To-day and To-morrow" by W. F. G. Swann. The number of accessions to the Library during the year was 4,281 , bringing the total of holdings to 167,135 , and the number of journals currently received rose to 1,336 , including nineteen Russian journals and fourteen English translations of Russian serial publications.

In recent years the part played by the Institute in the scientific life of the United States of America has grown greatly in importance, mainly because of the work of the Institute's Laboratories and the series of technical symposia and conferences sponsored by the Institute. The symposium on space medicine electronics, held in the spring, and the international symposium on gas-lubricating bearings, held in the autumn, attracted large audiences from afar. The Computing Centre, which completed its third year of operation in 1959 and its first year as a separate activity, drastically reduced its machine-use charges and many more industrial firms availed themselves of its services. Contracts received during 1959 by the Institute's Research and Development Laboratories passed the four million dollar mark for the first time. New equipment included the latest model electron-microscope and Varian instruments used in studies of nuclear and electron-spin resonance. Projects undertaken included the production of an ultra-pure iron bar of 1-in. diameter by zone refining; apparatus to measure speed by detecting the light of an ionized gas at two points along the travel of a 